\title{
Hubungan Tingkat Pengetahuan Prenatal Yoga dengan Minat Ibu Hamil dalam Mengikuti Kelas Prenatal Yoga di Puskesmas Putri Ayu Jambi
}

\author{
Nurbaiti $^{1}$, Suci Rahmani Nurita ${ }^{2}$ \\ ${ }^{1,2}$ Prodi D III kebidanan STIKes Baiturrahim Jambi \\ Email:nbaiti812@gmail.com
}

Submitted : 13/01/2020

Accepted: 06/02/2020

Published: 14/03/2020

\begin{abstract}
Pregnancy is a natural event experienced by a mother. During pregnancy, the mother will experience physical and mental changes. Changes that occur even provide discomfort for the mother such as back pain, aches in the legs, anxiety, and so forth. Pregnant women are in need of a healthy and fit body, and a relaxed mind, where this condition can be obtained by seeking a regular diet, adequate rest and exercise. To maintain the health of pregnant women pregnancy care needs to be done. One of the treatments for pregnancy is to practice yoga exercises.This study aims to determine the relationship of prenatal yoga knowledge level with the interest of pregnant women in taking prenatal yoga classes. This study uses a cross sectional research design that aims to determine the relationship of the level of prenatal yoga knowledge with the interest of pregnant women in taking prenatal yoga classes at the Puskesmas Putri Ayu in Jambi City. The study population was pregnant women who came to the Puskesmas Putri Ayu Kota Jambi. The sample in this study was taken using accidental sampling techniques as many as 32 people. This research was conducted from January-August 2019 at the Putri Ayu Public Health Center in Jambi City. The results showed that more than half of respondents had good knowledge about yoga (56.3\%) and more than half of respondents had a high interest in taking prenatal yoga classes (59.4\%). There was a significant relationship between the level of prenatal yoga knowledge with interest mothers in taking prenatal yoga classes $(p=0.006)$. It is expected that the Putri Ayu Public Health Center can improve health programs, especially programs for increasing the knowledge of pregnant women about the benefits of prenatal yoga in pregnancy.
\end{abstract}

Keywords: interests, knowledge, prenatal yoga, yoga classes

\begin{abstract}
Abstrak
Kehamilan merupakan peristiwa alamiah yang dialami oleh seorang ibu. Perubahan yang terjadi bahkan memberikan ketidaknyamanan bagi ibu seperti sakit pada punggung, pegal pada kaki, cemas, dan lain sebagainya. Ibu hamil sangat membutuhkan tubuh yang sehat dan bugar, serta pikiran yang rileks, dimana kondisi ini dapat diperoleh dengan mengupayakan pola makan yang teratur, istirahat yang cukup dan olah tubuh.Untuk memelihara kesehatan ibu hamil perlu dilakukan perawatan kehamilan. Salah satu perawatan kehamilan adalah dengan berlatih senam yoga. Penelitian ini bertujuan untuk mengetahui hubungan tingkat pengetahuan prenatal yoga dengan minat ibu hamil dalam mengikuti kelas prenatal yoga. Penelitian ini menggunakan desain penelitian cross sectional yang bertujuan untuk mengetahui hubungan tingkat pengetahuan prenatal yoga dengan minat ibu hamil dalam mengikuti kelas prenatal yoga di Puskesmas Putri Ayu Kota Jambi. Populasi penelitian adalah ibu hamil yang datang ke Puskesmas Putri Ayu Kota Jambi. Sampel dalam penelitian ini diambil dengan menggunakan teknik accidental sampling sebanyak 32 orang. Penelitian ini dilaksanakan dari bulan Januari-Agustus 2019 di Puskesmas Putri Ayu Kota Jambi. Hasil penelitian menunjukkan lebih dari separuh responden memiliki pengetahuan yang baik tentang yoga $(56,3 \%)$ dan lebih dari separuh responden memiliki minat yang tinggi dalam mengikuti kelas prenatal yoga $(59,4 \%)$. Terdapat hubungan yang bermakna antara tingkat pengetahuan prenatal yoga dengan minat ibu dalam mengikuti kelas prenatal yoga $(p=0,006)$. Diharapkan kepada Puskesmas Putri Ayu untuk dapat meningkatkan program kesehatan khususnya program peningkatan pengetahuan ibu hamil tentang manfaat prenatal yoga dalam kehamilan.
\end{abstract}

Kata Kunci: kelas yoga, minat ibu hamil, pengetahuan, prenatal yoga 


\section{PENDAHULUAN}

Dunia kembali merumuskan komitmen global dalam bidang kesehatan untuk 15 tahun ke depan. Kali ini diberi nama Sustainable Development Goals (SGDs) yang akan dicapai sampai dengan tahun 2030. SDGs atau tujuan pembangunan berkelanjutan ini hadir menggantikan Millenium Development Goals (MDGs) yang disepakati oleh 198 negara di tahun 2000 (Kemenkes RI, 2016). Kehamilan merupakan peristiwa alamiah yang dialami oleh seorang ibu. Namun, bagi ibu yang hamil pertama kali, hal ini sering dianggap sebagai peristiwa yang mencemaskan. Banyak ibu hamil akan mengurangi pekerjaan yang membutuhkan tenaga sehingga otot-otot dan sendi dalam tubuh semakin tidak efisien yang berakibat tidak elastisnya otot dan sendi. Pada masa kehamilan, ibu akan mengalami perubahan fisik maupun mental. Perubahan yang terjadi bahkan memberikan ketidaknyamanan bagi ibu seperti sakit pada punggung, pegal pada kaki, cemas, dan lain sebagainya. Ibu hamil sangat membutuhkan tubuh yang sehat dan bugar, serta pikiran yang rileks, dimana kondisi ini dapat diperoleh dengan mengupayakan pola makan yang teratur, istirahat yang cukup dan olah tubuh. Untuk memelihara kesehatan ibu hamil perlu dilakukan perawatan kehamilan. Salah satu perawatan kehamilan adalah dengan olahraga. ibu hamil yang berolahraga secara teratur,tingkat laporan ketidaknyamanan selama proses kehamilan lebih rendah, dan penyembuhan lebih cepat dibandingkan dengan yang tidak berolahraga selama kehamilan. Bagi yang giat berolahraga, membutuhkan sedikit intervensi Sectio Caesarea (SC) dan dapat memperpendek kala I dan kala II persalinan dibandingkan dengan yang tidak berolahraga.

Salah satu olahraganya adalah dengan berlatih senam yoga. Yoga adalah jenis olah tubuh, pikiran dan mental yang sangat membantu ibu hamil dalam melenturkan persendian, termasuk menenangkan pikiran.Yoga bermanfaat untuk kesehatan ibu seperti menjaga ibu supaya tetap bugar, rileks, percaya diri dan cira tubuh, perbaikan sikap tubuh, mengurangi stres, meningkatkan ketenangan dan ketentraman hati selama kehamilan. Yoga tidak boleh dilakukan oleh ibu yang mempunyai riwayat keguguran, ibu hamil dengan preeklamsi, placenta previa, ibu hamil dengan perdarahan selama kehamilan. Faktor yang mempengaruhi minat ibu hamil dalam mengikuti kelas prenatal yoga antara lain adalah Faktor dari dalam; Kepercayaan diri, Kepribadian, Perasaan, persepsi. Dan Faktor dari luar; Jenis kelamin, Tingkat Pengetahuan, Tingkat pendidikan

Puskesmas Putri Ayu adalah salah satu Puskesmas yang sudah memberikan pelayanan senam hamil tapi belum pernah memberikan pelayanan yoga dalam kehamilan, dengan alasan belum ada tenaga yang terlatih di Puskesmas tersebut. Penelitian ini bertujuan untuk mengetahui hubungan tingkat pengetahuan prenatal yoga dengan minat dalam mengikuti kelas prenatal yoga di Puskesmas Putri Ayu Kota Jambi

\section{METODE PENELITIAN}

Penelitian ini merupakan penelitian analitik yang bertujuan untuk mengetahui Hubungan tingkat pengetahuan prenatal yoga dengan minat ibu hamil dalam mengikuti prenatal yoga. Penelitian ini dilakukan di Puskesmas Putri Ayu Kota Jambi pada bulan Februari sampai September 2019. Populasi dalam penelitian ini adalah seluruh ibu hamil yang ada di Puskesmas Putri Ayu berjumlah 301 orang, besar sampel dalam penelitian ini adalah 32 orang dengan tehknik pengambilan sampel accidental sampling. Tehnik pengumpulan data di peroleh dari responden yaitu menggunakan kuesioner. Analisis data yang dilakukan adalah analisis univariat 
untuk mendapat gambaran distribusi frekuensi dari masing-masing variabel yang diteliti yaitu variabel independen dan variabel dependen. Selain itu juga analisis bivariat digunakan untuk mencari hubungan antara variabel dependen dan variabel independen melalui uji statistik. Uji statistik yang digunakan ialah Uji chi square untuk mengetahui hubungan antar tingkat pengetahuan dengan minat ibu hamil dalam mengikuti kelas prenatal yoga.

\section{HASIL DAN PEMBAHASAN}

\section{Analisis univariat}

\section{Pengetahuan}

Tabel 1 Distribusi tingkat Pengetahuan Responden Mengenai Prenatal Yoga dalam Mengikuti Kelas Prenatal Yoga di Puskesmas Putri Ayu Kota Jambi Tahun 2019

\begin{tabular}{lll}
\hline Pengetahuan & $\mathrm{n}$ & $\%$ \\
\hline Cukup & 4 & 43,8 \\
Baik & 8 & 56,3 \\
Total & 12 & 100 \\
\hline
\end{tabular}

Berdasarkan tabel dapat dilihat lebih separuh responden memiliki pengetahuan yang baik tentang yoga sebanyak 18 orang $(56,3 \%)$. Pengetahuan adalah hasil tahu dan ini terjadi setelah orang melakukan penginderaan terhadap suatu obyek tertentu. Seseorang yang memiliki pengetahuan yang luas khususnya tentang kesehatan maka seseorang itu akan cenderung dan senantiasa meningkatkan kesehatan diri, keluarga dan lingkungannya (Notoadmojo, 2010).

Faktor pendidikan ibu yang lebih tinggi cenderung pengetahuan ibu juga semakin luas. Berdasarkan hasil penelitian, sebagian besar responden berpendidikan SMA atau sederajat. Hal ini sejalan dengan teori Notoadmojo (2010) bahwa salah satu faktor yang mempengaruhi pengetahuan adalah pendidikan. Pendidikan adalah untuk mengembangkan kepribadian dan kemampuan didalam maupun diluar sekolah yang berlangsung seumur hidup.
Sehingga jika memiliki pendidikan yang tinggi maka pengetahuannya pun akan tinggi tetapi jika pendidikannya rendah maka pengetahuannya akan rendah.

Pengetahuan responden yang baik tentang yoga juga disebabkan oleh informasi tentang yoga yang pernah didapat oleh responden. Dari hasil penelitian, lebih dari separuh responden mengatakan pernah mendapatkan informasi mengenai yoga dimana separuh mendapat informasi dari tenaga kesehatan dan separuh lagi mendapat informasi dari media elektronik. Menurut Green (1980) dalam Notoatmodjo (2010), perilaku pemanfaatan pelayanan kesehatan dipengaruhi oleh banyak faktor diantaranya faktor pendorong yang terwujud dari sikap dan perilaku petugas kesehatan.

Usia responden juga berpengaruh terhadap tingkat pengetahuan responden. Dari hasil penelitian didapatkan rerata usia responden adalah 29,34 $\pm 7,49$ tahun. Pertambahan usia seseorang akan menyebabkan terjadi perubahan aspek fisik dan psikologis dimana taraf berpikir seseorang semakin matang dan dewasa. Namun dalam penerimaan informasi, semakin muda usia informan maka akan lebih mudah menyerap dan menerima informasi dibandingkan dengan usia yang lebih tua (Latuharhary, dkk. 2014).

\section{Minat}

Tabel 2 Distribusi Minat Responden dalam Mengikuti Kelas Prenatal Yoga di Puskesmas Putri Ayu Kota Jambi Tahun 2019

\begin{tabular}{ccc}
\hline Minat & $\mathrm{n}$ & $\%$ \\
\hline Sedang & 13 & 40,6 \\
Tinggi & 19 & 59,4 \\
Total & 32 & 100 \\
\hline
\end{tabular}

Berdasarkan tabel 2 dapat dilihat lebih separuh responden memiliki minat tinggi dalam mengikuti kelas prenatal yoga sebanyak 19 orang $(59,4 \%)$. Minat berarti kecenderungan dan kegairahan yang tinggi atau keinginan yang besar terhadap sesuatu 
(Syah, 2010). Pada setiap orang, minat berperan sangat penting dalam kehidupannya. Minat mempunyai dampak yang besar atas perilaku dan sikap seseorang. Didalam belajarpun minat dapat menjadi sumber motivasi yang kuat dalam mendorong seseorang untuk belajar (Suharyat, 2009).

Minat merupakan keinginan individu untuk melakukan perilaku tertentu sebelum perilaku tersebut dilaksanakan. Adanya niat/minat untuk melakukan suatu tindakan akan menentukan apakah kegiatan tersebut akhirnya akan dilakukan. Kegiatan yang dilakukan inilah yang disebut dengan perilaku. Dengan demikian perilaku merupakan 'niat/minat' yang sudah direalisasikan dalam bentuk tingkah laku yang tampak (Hayati, 2007).

Dalam teori Tindakan Beralasan diuraikan bahwa kehendak/minat dipengaruhi oleh sikap dan norma subyektif. Teori ini menghubungkan keyakinan (belief), sikap (attitude), kehendak/ niat/minat (intention) dan perilaku. Keyakinan terhadap manfaat suatu kegiatan atau hal tertentu akan menimbulkan sikap positip terhadap kegiatan atau hal tersebut. Sikap positif akan mempengaruhi niat/minat seseorang untuk melakukan kegiatan tersebut. Sikap ini merupakan hasil pertimbangan untung dan rugi dari perilaku tersebut (Hayati, 2007).

\section{Analisis Bivariat}

Tabel 3. Hubungan Tingkat Pengetahuan Prenatal Yoga Dengan Minat Ibu Hamil Dalam Mengikuti Kelas Prenatal Yoga

\begin{tabular}{|c|c|c|c|c|c|c|c|}
\hline \multirow{3}{*}{$\begin{array}{l}\text { Penge- } \\
\text { tahuan }\end{array}$} & \multicolumn{4}{|c|}{ Minat } & \multirow{2}{*}{\multicolumn{2}{|c|}{ Total }} & \multirow{3}{*}{$\mathrm{p}$} \\
\hline & \multicolumn{2}{|c|}{ Sedang } & \multicolumn{2}{|c|}{ Tinggi } & & & \\
\hline & $\mathrm{n}$ & $\%$ & $\mathrm{n}$ & $\%$ & $\mathrm{n}$ & $\%$ & \\
\hline Cukup & 10 & 71,4 & 4 & 28,6 & 14 & 100 & \\
\hline Baik & 3 & 16,7 & 15 & 83,3 & 18 & 100 & .006 \\
\hline Total & 3 & 40,6 & 19 & 59,4 & 32 & 100 & \\
\hline
\end{tabular}

bahwa dari total 32 responden, 18 responden yang memiliki pengetahuan baik, sebanyak 15 responden $(83,3 \%)$ memiliki minat tinggi untuk mengikuti kelas yoga. Dari 14 responden yang memiliki pengetahuan cukup, sebanyak 10 responden $(71,4 \%)$ memiliki minat sedang untuk mengikuti kelas yoga. Dari hasil uji statistik diperoleh $p$-value 0,006 ( $p$-value < 0,05) yang berarti terdapat hubungan antara tingkat pengetahuan prenatal yoga dengan minat ibu dalam mengikuti kelas prenatal yoga.

Hal ini sejalan dengan hasil penelitian Rahma dan Prabandari (2012) pada Wanita Usia Subur (WUS) mengenai minat WUS dalam melakukan pemeriksaan IVA bahwa semakin kurang pengetahuan seseorang semakin rendah juga minatnya, jika pengetahuan cukup maka minatnya sedang dan sebaliknya, semakin baik pengetahuan seseorang semakin tinggi juga minat dalam melakukan pemeriksaan IVA.

Sejalan dengan hasil penelitian Apriani dan Suesti (2012) menunjukkan bahwa terdapat hubungan yang signifikan antara pengetahuan tentang kanker serviks dengan minat metode IVA dan papsmear dengan korelasi sedang $(\mathrm{p}=0,000, \mathrm{r}=0,541)$. Pengetahuan seseorang tentang yoga dapat meningkatkan minat untuk mengikuti kelas prenatal yoga dikarenakan pengetahuan bagus maka seseorang akan lebih peduli terhadap kesehatan dirinya.

Minat mengandung unsur-unsur yang terdiri dari kognisi (mengenal), emosi (perasaan), dan konasi (kehendak). Unsur kognisi, dalam arti minat itu didahului oleh pengetahuan dan informasi mengenai objek yang dituju oleh minat tersebut. Unsur emosi karena dalam partisipasi atau pengalaman itu disertai dengan perasaan tertentu (perasaan senang) sedangkan unsur konasi merupakan kelanjutan dari kedua unsur tersebut yaitu yang diwujudkan dalam bentuk kemauan dan hasrat untuk melakukan suatu kegiatan. Hal ini berarti untuk meningkatkan minat ibu hamil untuk mengikuti kelas prenatal yoga, perlu terlebih dahulu untuk meningkatkan 
pengetahuannya mengenai prenatal yoga (Suharyat, 2009).

\section{SIMPULAN}

Berdasarkan analisis hasil dan pembahasan dari penelitian yang dilakukan dapat disimpulkan bahwa lebih separuh responden memiliki pengetahuan yang baik tentang yoga sebanyak 18 orang $(56,3 \%)$. Lebih separuh responden memiliki minat yang tinggi dalam mengikuti kelas prenatal yoga sebanyak 19 orang $(59,4 \%)$. Terdapat hubungan antara tingkat pengetahuan prenatal yoga dengan minat ibu dalam mengikuti kelas prenatal yoga $(p=0,006)$

Diharapkan kepada Puskesmas Putri Ayu untuk dapat meningkatkan program kesehatan khususnya program peningkatan pengetahuan ibu hamil tentang manfaat prenatal yoga.

Perlu dilakukannya penelitian lebih lanjut tentang faktor-faktor yang mempengaruhi minat ibu hamil untuk mengikuti kelas prenatal yoga selain pengetahuan.

\section{DAFTAR PUSTAKA}

Apriani, E. P., \& Suesti, S. (2013). Hubungan Pengetahuan tentang Kanker Serviks dengan Minat Metode IVA dan Papsmear pada Ibu-Ibu Perkumpulan RT di Dukuh Gamping Kidul Ambarketawang Gamping Tahun 2013 (Doctoral dissertation, STIKES'Aisyiyah Yogyakarta).

Asrinah dkk. (2010). Konsep kebidanan. Yogyakarta. Graha ilmu

Astuti Puji. (2012). Asuhan kebidanan masa kehamilan. Yogyakarta. Graha ilmu

Bobak, Lowdermilk, Jensen, (2004). Buku Ajar Keperawatan Maternitas / Maternity Nursing. Alih Bahasa Maria A. Wijayanti. Peter I. Anugerah, edisi 4. Jakarta : EGC.

Hayati, R. N. (2007). Pengaruh Pengetahuan, Sikap dan Motivasi
Terhadap Minat Bidan Mengikuti Uji Kompetensi Di Kota Semarang Tahun 2007 (Doctoral dissertation, program Pascasarjana

Universitas Diponegoro).

Latuharhary, F. T., Suparman, E., \& Tendean, H. M. (2014). Pengetahuan Ibu Hamil Tentang Inisiasi Menyusu Dini. e-CliniC, 2(2).

Notoadmodjo, S. (2010). Ilmu Perilaku Kesehatan. PT Rineka Cipta. Jakarta.

Notoadmodjo, S. (2010). Konsep Motivasi. PT Rineka Cipta. Jakarta.

Notoadmodjo, S. (2010). Metodologi Penelitian Kesehatan. Rineka Cipta. Jakarta.

Notoatmodjo,Soekidjo. (2012). Promosi Kesehatan dan Ilmu Perilaku. PT Rineka Cipta. Jakarta.

Nursalam. (2015). Konsep dan penerapan metodologi penelitian ilmu keperawatan. Surabaya Salemba Medika.

Purwanto. (2011). Instrumen penelitian soaial dan pendidikan. Yogyakarta. Pustaka Pelajar.

Rahma, R. A. \& Prabandari, F. 2012. Beberapa Faktor yang Mempengaruhi Minat WUS dalam Melakukan Pemeriksaan IVA di desa Pangebatan Kecamatan Karanglewas Kabupaten Banyumas Tahun 2011. Bidan Prada:Jurnal Ilmiah Kebidanan. Vol.3 (1). pp.1-14.

Suharyat, Y. (2009). Hubungan antara sikap, minat dan perilaku manusia. Jurnal Region, 1(3), 1-19.

Tim Trainner renatal Gentle Yoga.(2016). Modul prenatal gentle Yoga. Kristara.

Ummi. (2010). Asuhan kebidanan pada kehamilan fisiologis. Jakarta: Salemba Medika

World Health Organization. (2006). Neonatal and Perinatal Mortality. Switzerland : WHO Press 